\title{
What should I do if I'm being investigated by the GMC?
}

Abi Rimmer asks what doctors should do when they receive a GMC letter about a complaint from a patient

\section{Abi Rimmer}

BMJ Careers

\section{"Ask for support" \\ Ellie Mein, medicolegal adviser, Medical Defence Union}

"It's understandable to be worried if you've received a letter from the General Medical Council (GMC). But bear in mind that only $18 \%$ of complaints made to the GMC reach a full investigation.

"Before responding to the GMC, contact your medical defence organisation as soon as possible to get advice. Cooperate fully with the council's process and your employer's requirements. Complete and return the GMC's work details form within seven days.

"If you're a GP you'll need to inform your employer and NHS England or your health board. Also consider telling your medical director and any organisation to which you provide services.

"Don't let the complaint affect the care you provide to the patient who complained. If the breakdown of trust means that you can't provide good clinical care to the patient and you're considering ending the professional relationship, seek advice from your medical defence organisation. The GMC makes it clear that 'you must not allow a patient's complaint to adversely affect the care or treatment you provide or arrange.'

"Review the concerns raised, with a trusted senior colleague. Take forward any learning points for future practice, and document this.

“And ask for support. Don't underestimate the effect an investigation can have on your health and wellbeing. Confide in a trusted colleague, friend, or relative while maintaining patient confidentiality."

\section{“Look after yourself”}

\section{Tony Banerjee, GP, Hurley Group}

"Inform your indemnity organisation. This will give you the opportunity to get a medicolegal stance on the complaint and how to proceed.

“Tell your colleagues, and if you're a GP tell your partners and practice manager. Your peers will be good support in moving forwards and will give you a balanced view on the complaint itself. This will also help with taking time off to meet with your indemnity organisation or solicitor if you need to.

"Keep a contemporaneous diary of events: this will be useful to you as the complaint progresses. Be prepared for a long process. Complaints can often take several months to be investigated. And comply fully with the council's process: let it know about any impending annual leave, and be prompt with your responses to GMC correspondence.

"Use your support networks. Just talking it through with someone can give you a different perspective. Contact the BMA's doctor support service, ${ }^{2}$ which helps doctors facing GMC investigations. Consider registering with the Practitioner Health Programme for further support and guidance.

"Remember: you're not the only one going through this. The GMC receives over 10000 complaints each year against UK doctors, so don't isolate yourself.

"Look after yourself. These investigations can be physically, emotionally, and psychologically demanding. Visit your GP and get the help that you need."

\section{"Don't be afraid to reach out" John Smyth, case examiner, General Medical}

"Receiving a complaint can be upsetting and stressful. It's important to remember that only a small proportion of GMC investigations result in regulatory action. We take action in cases where there has been a serious or repeated breach of our guidance, and erasure is extremely rare.

"Our advice for doctors is to stay calm, read over what's detailed in the GMC letter, and seek advice at an early stage from someone who understands our processes, such as a medical defence organisation. All doctors under investigation can also access free, confidential support through the doctor support service, ${ }^{2}$ which we commission the BMA to run. And don't be frightened to ask for support from your GP or others if you need it.

"Every complaint letter includes a GMC contact who can provide more information. Doctors shouldn't feel afraid to reach out to get the details they need or to request a representative to phone on their behalf. 
"We understand that this can be a difficult time for doctors, and we've taken steps to reduce the impact of our processes. In recent years we've improved our communications, invested in support services, and introduced provisional inquiries to reduce the number of full investigations.

"We want to deal with complaints as quickly and fairly as possible, for patients and for doctors."
1 General Medical Council. Good medical practice. 25 March 2013. https://www.gmc-uk. org/ethical-guidance/ethical-guidance-for-doctors/good-medical-practice.

2 BMA. Doctor support service. https://www.bma.org.uk/advice/work-life-support/yourwellbeing/doctor-support-service.

Published by the BMJ Publishing Group Limited. For permission to use (where not already granted under a licence) please go to http://group.bmj.com/group/rights-licensing/ permissions 